This item was submitted to Loughborough's Research Repository by the author.

Items in Figshare are protected by copyright, with all rights reserved, unless otherwise indicated.

\title{
Sustainable aviation futures: crises, contested realities and prospects for Change
}

PLEASE CITE THE PUBLISHED VERSION

http://dx.doi.org/10.1108/S2044-9941(2013)0000004013

PUBLISHER

(c) Emerald Group Publishing

VERSION

SMUR (Submitted Manuscript Under Review)

LICENCE

CC BY-NC-ND 4.0

REPOSITORY RECORD

Budd, Lucy C.S., Steven Griggs, and David Howarth. 2019. "Sustainable Aviation Futures: Crises, Contested Realities and Prospects for Change". figshare. https://hdl.handle.net/2134/17613. 


\title{
Chapter 1
}

\section{Sustainable Aviation Futures: Crises, Contested Realities, and Prospects for Change}

\author{
Lucy Budd, Steven Griggs and David Howarth
}

\begin{abstract}
Purpose

This chapter critically examines the fault-lines structuring contemporary debates on the politics and policy of aviation. In so doing, it generates different scenarios for the future of air travel.
\end{abstract}

\section{Originality}

This chapter demonstrates the importance of the competing frames constituting the contested realities of air transport. Its mapping of the fault-lines of aviation politics and policy inform what it determines to be post-carbon, high-modernist, market regulation and demand management scenarios for the future of aviation.

\section{Methodology/approach}

The chapter undertakes a critical review of existing literature, policy reports and stakeholder briefings, using the definition of sustainable development as a heuristic device to map and identify the fault-lines structuring contemporary debates on aviation futures. It then builds upon this analysis to constitute four different scenarios for the future of flying.

\section{Findings}

The chapter demonstrates the contested realities of aviation politics. It re-affirms the political nature of the fault-lines, which structure contemporary understandings of aviation. These fault-lines, the analysis suggests, are re-constituted in part by appeals to the ambiguities and contradictions of competing evidence-bases or policy frames. Any reframing of aviation policy and politics therefore ultimately rests on the outcome of political negotiations and persuasion, our broader views of the future challenges facing society, and how governments and other stakeholders put in place and coordinate the multiple arenas in which a dialogue over the future of aviation can be held. Aviation futures cannot be reduced to the narrow confines of the technical merits or claims surrounding the feasibility of policy instruments.

Keywords: air travel; airports; aviation economics; sustainable development; environment; aviation futures.

'Crisis' is a term often swiftly attached to industries, governments and indeed societies, only to be withdrawn at some later date as the expected threats fail to appear or are met with new policy instruments and adjustments. Such crises are, in fact, relatively easily constrained, capable of being offset by policy learning or changes to our standard ways of working. Yet, recourse to such crisis-narratives should not always be dismissed as 'crying wolf'. The threats and dangers are often very material indeed, to the point where some cannot be simply warded off by innovative or ingenious strategies. Rather, they require the generation of alternative futures, which recast the existing regimes, systems, structures and practices through which an industry, government or society operates. Put alternatively, 'crisis' may well in certain conjunctures demand the radical transformation of how we view the world, putting into question our fundamental values and beliefs; and for this to 
happen, protagonists have arguably to recognise that they face a 'crisis' and that continuing as usual is no longer an option.

Whether the commercial aviation industry faces a crisis is a moot point, generating different judgements and controversies which in turn quickly trigger further rounds of questions and debates. Not least among which is that if aviation is in crisis, it is a crisis of what and for whom? For some commentators, and not just those advancing future imaginaries of mega-airport cities or aerotropoli (Kasarda and Lindsay, 2012), the notion of 'crisis' may be a strange, if not contentious, point of departure for any discussion of the future of aviation as air transport globally is arguably in good health. Since the end of the Second World War, demand for passenger and cargo flights has increased dramatically to the point where 2.8 billion passengers and 48 million tonnes of airfreight flew around the world in 2012 (Figure 1 and ATAG, 2012). Currently, in the region of 1700 commercial airlines (operating over 20,000 aircraft) fly 30 million commercial flights between 3,750 airports worldwide every year (ATAG, 2012; Airlines for America, 2013). However, the spatial distribution of these services is highly uneven with the majority of flights being concentrated at major cities in the economically developed world. Crucially, however, although certain air transport markets, including those in North America and parts of Western Europe, are believed to be close to saturation, others, particularly in the rapidly developing economies of Latin America and the Middle and Far East (including most notably Brazil, the United Arab Emirates, China, Indonesia and the Philippines), are rapidly expanding, leading to growing demand and a net increase in flights (Boeing, 2012). Given the growth potential of these markets, the International Air Transport Association (IATA) has forecast an annual global passenger growth rate of 5.3 per cent from 2013 to 2016, by which time 3.6 billion passengers are expected to fly each year (IATA, 2012a).

Figure 1: Growth in global airline Revenue Passenger Kilometres (RPKs) and airfreight, 1945-2011.

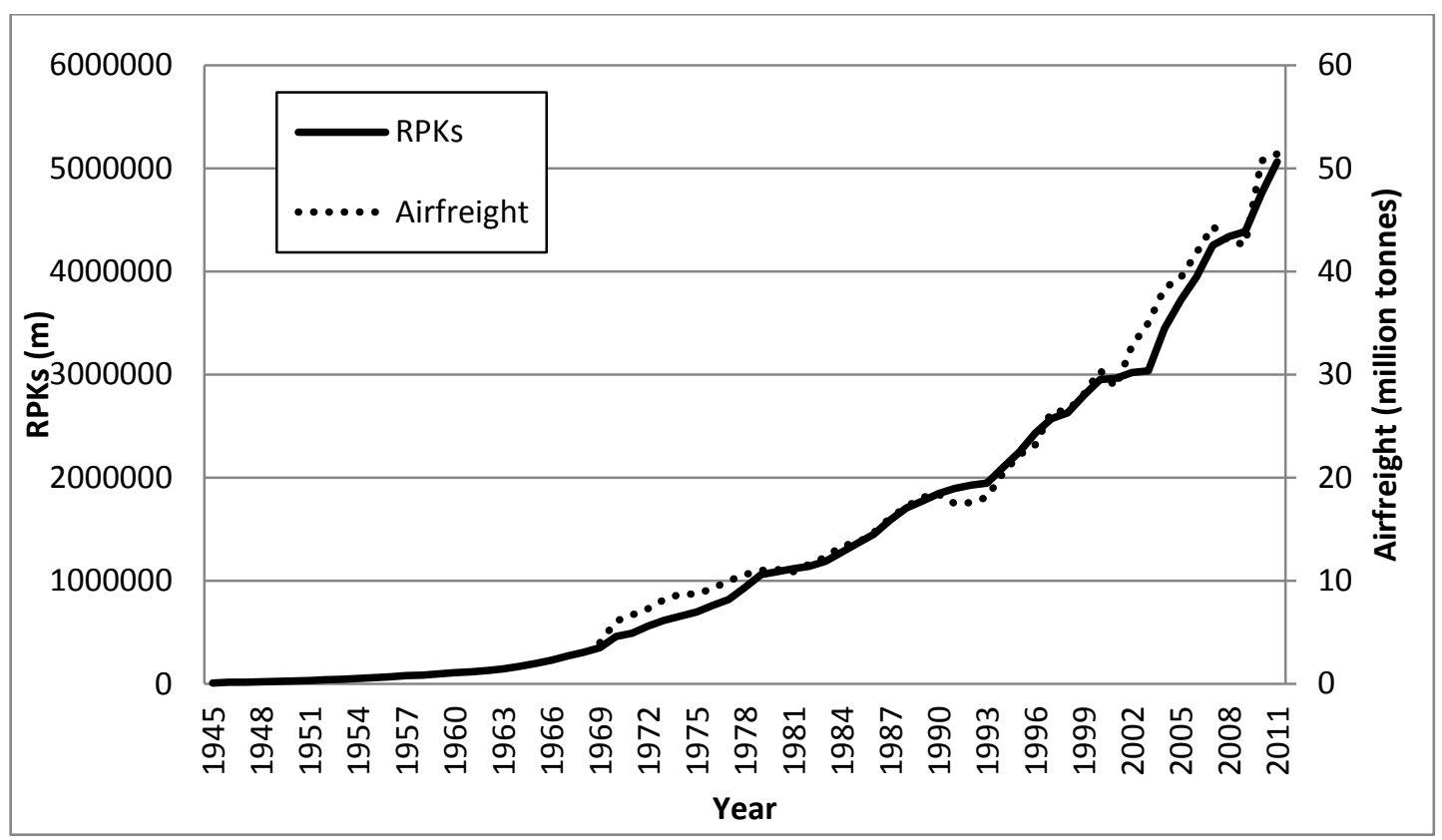

Source: Data derived from Airlines for America, 2013.

The inexorable expansion of commercial air transport after the Second World War, which actually accelerated at the end of the last century thanks, in part, to global policies of airline deregulation and the emergence of low-cost carriers, appears in 
the eyes of industry representatives unlikely to falter in the near future. Talk of a crisis in such circles is perhaps a little premature unless it refers to a crisis of airport capacity and of routes between these new destinations and mature markets. In its 'most likely' scenario for the development of the European aviation market in 2035, Eurocontrol (2013: 15) foresees 1.5 times more commercial air traffic movements than in 2012. It predicts that growth will be most robust in Eastern Europe and more rapid for traffic to and from Europe than within the continent while Turkey will generate more additional flights than any other country. As John Bowen explains in Chapter 2 of this volume, the contours of the global aviation industry are being progressively redrawn as a result of changes to the regulatory environment and the global economy, but this does not constitute a crisis of aviation per se. A similar line of argument may be taken towards the restructuring of the industry. Following market liberalisation and the 2008 global recession in particular, a number of major carriers have collapsed and significant market adjustments have occurred in response to the competitive threat posed by low-cost carriers, the shifting balance between leisure and business travel and the withdrawal of routes and concomitant reduction in passenger numbers at certain airports. Such adjustments are, however, to be expected and do not in themselves signal any long-term crisis of demand.

Paradoxically, the apparent resilience of the global aviation sector as a whole and the growing demand for air travel in new markets has inculcated it into a further set of interconnected social, economic and environmental crises. Put simply, flying, or rather mass aeromobility, with all its systems, structures, procedures, practices and languages, has immersed itself in our everyday lives. It has shifted our conceptions of time and space, offered us new mobilities, quickened practices of globalisation, and contributed to the development of the global neoliberal order in the second half of the twentieth century (Urry, 2009). This has come to constitute over time what Urry and others suggests is a culture of 'air-mindedness', which goes beyond the departure lounge or airport terminal and which spreads its tentacles out into how we think about and structure our economy, organise our social interactions and plan our urban and rural futures (Urry, 2009: 25, 36; see also Adey, 2010; Randles and Mander, 2009). As a result, how we celebrate landmark events in our lives, go on holiday, organise sporting events, choose the food we shop for at the local supermarket, keep in contact with colleagues and relatives, manage and forge business partnerships, profit from foreign markets, conduct international diplomatic relations, understand migration and communicate with one another are all increasingly shaped by our experiences, and possibilities of, air travel.

But, it is the very pervasiveness of the expansionist logic of air travel that locks aviation firmly into a set of contradictory challenges, the origins of which might not solely lie within the practices of flying, but which amount nonetheless to a transformational crisis or series of crises for aviation. Indeed, it is hard to refute that, alongside the highly contentious issues of airport expansion, location, noise pollution and quality of life for those living near airports, a further litany of charges and threats against aviation have been added to its balance-sheet, from security and safety concerns, public health fears, and social injustice, to the spread of new forms of corporate imperialism, visions of ever-expanding urbanisation and 'faster living', and the threat of peak oil and our reliance on fossil fuels, which challenge the very existence of mass aviation. More significantly however, in both scientific and public discourse, aviation has been repeatedly identified as a growing contributor of carbon emissions greenhouse gases and tied inescapably to the universal challenge of climate change.

The salient and very public link between air travel and climate change has done much since the start of the $21^{\text {st }}$ century to begin to dislodge the dominant narrative of global aviation success and the economic necessity of its expansion (Griggs and 
Howarth, 2013). Aviation, or specifically its capacity for further expansion, as well as many of the carbon-intensive practices it supports, have been challenged as being incompatible if not wholly contradictory with government policies to tackle climate change (Anderson et al., 2005; Cairns and Newson, 2006; see Bows-Larkin and Anderson, Chapter 3, and Anger-Kraavi and Köhler, Chapter 5, in this volume). Commercial aviation currently accounts for around 3 per cent of all carbon dioxide $\left(\mathrm{CO}_{2}\right)$ emissions that result from human activities, but growing demand for air travel and emissions reductions in other sectors means that its total contribution is likely to increase. In the United Kingdom, the Committee on Climate Change (2009) has predicted that commercial aviation's contribution to UK greenhouse gases will rise to 25 per cent by 2050 if aviation continues to expand. This scenario would require other sectors to reduce their emissions disproportionately if the UK is to meet its carbon reduction targets. In short, capacity constraints and congested skies might well continue to frustrate travellers and allegedly cause delays that cost the global economy billions of US dollars every year in lost productivity, but they are no longer the only game in town: climate change has challenged, or at least destabilised, the traditional boundaries of the policy and public debate.

Of course, such claims over the impact of aviation on climate change are heavily disputed. On the one hand, there are competing evidence bases and areas of uncertainty, such as the impact of contrails and aircraft emissions at high altitude on radiative forcing. On the other hand, there are on-going debates over the ability and effectiveness of technological change to lower aviation emissions (and over what timescale this might occur), as well as the stringency of domestic and international regulatory regimes and the viability of emissions trading, be it on a regional or global scale (see Anger-Kraavi and Köhler, Chapter 5 in this volume). For example, the UK's Committee on Climate Change in its 2009 report suggested that a 60 per cent growth in demand for air travel could be compatible with the commitment to keep $\mathrm{CO}_{2}$ emissions from commercial aviation in 2050 no higher than they were in 2005. This apparent mismatch between higher demand and lower emissions was explained through anticipated future fleet fuel efficiency, the use of alternative fuels, and enhanced air traffic management and operational procedures (CCC, 2009); technologies, which despite industry advances, are yet to enter widespread use (see Budd and Budd, Chapter 4 in this volume).

In fact, in the field of aviation, at least in mature markets, there has been a hardening of the political boundaries between rival coalitions as the 'new' politics of aviation protest has transformed campaigns against airport expansion (Griggs and Howarth, 2004). Early campaigns tended to mobilise against noise pollution and to conserve countryside and rural environments and protect the quality of life of residents living near airports or proposed sites for expansion. In many instances, protesters did not necessarily contest the expansion of aviation, but rather challenged the location of new airports or the appropriateness of the sites that had been selected for development (although the potential to broaden campaigns was always present as the campaign in the 1970s against Narita airport demonstrated (Apter and Sawa, 1984)). However, borrowing from the tactical repertoire of direct action movements and the availability of new discourses of sustainable development and the environment, local anti-airport campaigns have diversified their strategies and coupled flying to issues such as tackling climate change, advancing alternative forms of sustainable transport, challenging the limits of government decision-making, and addressing global justice, thereby forging universal campaigns against airport expansion at any site and indeed against air travel itself. In so doing, they have deepened alliances with environmental groups, anti-corporate lobbies, direct action networks and radical environmentalists, as well as trade unions, new farming movements, local authorities and celebrities, as the campaign against the third runway at London Heathrow and the construction of a 
new international airport on agricultural land at Notre-Dame-Des-Landes near Nantes in France have recently demonstrated.

These new coalitions against aviation expansion are, we suggest, part and parcel of the multiple crises facing the aviation industry in the second decade of the $21^{\text {st }}$ century. Griggs and Howarth (2013) argue that, in part, one of the successes of the new protests against airport expansion is the transformation of aviation from a 'tame' into a 'wicked' policy issue for government (Rittel and Webber, 1973). 'Wicked issues' are characterised by conflicting policy frames, each informed by competing evidence bases, rival definitions of problems and solutions, and antagonistic beliefs and values. They are multidimensional issues that cross traditional policy boundaries to such an extent that they are relatively immune to one-shot policy solutions and are fraught with unexpected consequences as acting on one aspect triggers negative consequences for other elements. As such, they present a complex set of interconnected economic, political and social governance challenges that require a reframing of the very issues at stake (Schön and Rein, 1995).

Against this background, aviation, or rather the issue of aviation, has become if not a 'crisis' at least an impasse for many governments and international bodies (Griggs and Howarth, 2013). Economic liberalisation and deregulation, as well as climate change, have further fragmented and multiplied the competing logics at play in the policy sphere of aviation, surfacing the dependency of any government on an array of external stakeholders, which includes other governments given the international regimes that regulate air travel, as well as global environmental lobbies, local resident groups, aviation environment organisations, international financial conglomerates, national airlines, low cost carriers, aviation regulators, and industry associations.

Critically, there is no broad consensus over the policy instruments, strategies and behavioural incentives that might permit governments and the aviation industry to address rising emissions. This ambiguity in both policy and practice derives, in part, from conflicting interpretations of the impact aviation emissions have on both the global climate and on local noise and air quality around airports. It also stems from uncertainties surrounding the nature of aviation's contribution to the global economy; the constraints imposed by international regulatory regime governing commercial aviation; the credibility of the predicted improvements in aeronautical technologies; the current capacity constraints of airport infrastructure; and the continuing rise in public demand for air travel (Gössling and Upham, 2009). Indeed, governments of all hues risk being caught between a current dependency on air travel and aeromobility and a broad recognition of the need for changes to the aviation industry and more importantly to the embedded social practices of flying (which, if not a reality for many across the globe, remain a desirable aspiration nonetheless).

It is these issues and challenges that this volume seeks to illuminate. As we suggest above, one starting point is to recognise the multiple and often contradictory crises facing the aviation industry, some of which are only in part the product of the internal contradictions of air travel. However, it is our contention that because flying has entered and shaped our social and economic practices to such an extent it cannot remain immune to such crises or be an industry that warrants special treatment. In addition we would countenance against quick appeals to positive-sum games through which aviation expansion and carbon reductions go hand in hand, particularly given the obstacles created by the global interdependencies of the industry. Indeed, the reframing of aviation policy will necessarily be fraught with technical and political difficulties, engage multiple, and often antagonistic, coalitions, 
and take place across all levels of society and government. With this in mind, in the next section, we start to analyse the tensions and contestations that inform contemporary understandings of 'sustainable aviation' in industrialised western economies. In particular, we set out the contested realities, ambiguities and contradictions of pursuing (or not) sustainable futures for aviation, which contributors to this volume then go on to explore.

\section{Contested Realities, Sustainable Futures and Aviation}

'Sustainable aviation', or rather the political battle to formulate and implement such policies, has come to increasingly dominate and structure the politics of contemporary air travel. Indeed, the very phrase 'sustainable aviation' is widely disputed - what political scientists and policy analysts often call a 'contested concept' (Walker and Cook, 2009). It has been dismissed as an oxymoron, while also being critically evaluated as an ideological move by governments and supporters of aviation expansion to ward off opposition to proposals to increase airport capacity (Griggs and Howarth, 2013). Yet, for others, 'sustainable aviation' as a package of workable policies is already on the horizon, driven by technological improvements and by international agreements on emissions trading. The proposed 2012 inclusion of international aviation in the European Union emissions trading scheme (ETS), for example, reduced certain elements of opposition to further expansion at London Heathrow on the grounds that increased capacity will not lead to increased emissions given the caps on emissions (Griggs and Howarth, 2013).

These disagreements are grounded not merely in competing interpretations of scientific knowledge or rival impact assessments of policy tools. They are rooted in different webs of ethical and ideological beliefs, diverse attitudes to risk and technology, and rival narratives of the past and visions of the future (Hulme 2009: $x x v i)$. In such circumstances, the resolution of differences is not straightforward or compatible with so-called appeals to objective evidence-bases, for what we might term to be different policy frames or discourses of aviation constitute the very problems and solutions, evidence bases, and understandings of aviation under scrutiny. In other words, 'flying' is a political construct which is constantly reconstructed and brought into being by different protagonists and practices. This assertion engages us not in the exploration of the reality of air travel, but in the critical analysis of its contested multiple realities.

In this section, we explore the different realities of aviation by analysing the contentious boundaries and fault-lines which organise on-going public dialogues over the future of 'sustainable aviation'. To structure this critical assessment, we borrow from the discourse of sustainable development. Sustainable development is widely understood, in the rhetoric of the Brundtland Commission (United Nations World Commission on Environment and Development 1987: chapter 2, para. 1), to mean 'development that meets the needs of the present without compromising the ability of future generations to meet their own needs.' As such, it advocates that individuals, firms, public bodies and governments must not prioritise one particular need over another, but consider how actions impact both positively and negatively on economic, social and environmental outcomes across societies. Importantly, such assessments must be grounded not merely in the short-term and decisionmakers must 'future-proof' policies so as not to compromise the opportunities of future generations.

Of course, any definition of sustainable development is itself highly contentious and subject to rival different interpretations, as our discussion of the meaning of 'sustainable aviation' has intimated. Equally, any assessment of the sustainability of 
air travel cannot evaluate its different contributions to wellbeing in isolation from one another. Yet, it must also avoid descending into narrow cost-benefit exercises, working instead, we suggest, from a broad vision of future needs and desires concerning the quality of life across societies. Here, we recognise such concerns, and we do not propose any definitive assessment of the sustainability of air travel. Rather, we deploy the widely accepted definition of the Brundtland Commission as a heuristic device to expose the competing sustainable futures of aviation and the fault-lines between them. Therefore, we first examine the competing interpretations of the economic, social and environmental impacts of air travel, before turning to how these different interpretations constitute multiple scenarios for the future of aviation. We turn first to the economic fault-line that informs different aviation futures.

\section{Claims for connectivity}

The aviation industry claims to employ directly over 8 million people across the globe (ATAG 2013). However, part and parcel of the narrative of the expansion of commercial aviation is its depiction as a 'vital' cog in the modern global economy and hence a driver of social progress. Aviation, it is often repeated, is a primary catalyst in the reproduction of the economic wellbeing of the modern nation-state as well as an agent of social progress within communities that provides more and more people with more and more opportunities for cultural interaction and exchange (Griggs and Howarth, 2013). In its briefing on the economic benefits of aviation, the International Air Transport Association (IATA) typically spells out these oft-lauded strategic advantages. It first acknowledges the direct employment benefits from air transport, but then foregrounds aviation's 'essential input' into the global economy through the increased connectivity air transport networks provide. 'Greater connections' by air, it suggests, drives growth by 'providing better access to markets, enhancing links within and between businesses and providing greater access to resources and international capital markets' (IATA, 2007: 1). Indeed, IATA's home webpage lists the economic benefits of aviation, presenting its visitors with the claims, amongst others, that '\$6.4 trillion of goods travel by air - that's 35\% of all world trade by value. Aviation delivers' or that ' $3.5 \%$ of the global economy relies on aviation. Aviation supports business' (IATA, 2013a, emphasis in original).

However, these claims are being increasingly challenged, constituting a growing fault-line in the politics of aviation. Airports have been transformed in recent years into commercial centres, with much of their profits coming not from aeronautical fees but from retail outlets and parking (Graham, 2008). Equally, it is suggested that the economic performance of aviation is falsely inflated by tax exemptions on aviation fuel and international services (a position enshrined in the 1944 Chicago Convention and the vast majority of bilateral air service agreements). In its pamphlet on aviation and climate change, GreenSkies (2005: 1), an international alliance of aviation environment and citizen organisations, argues that aviation enjoys huge tax breaks and is therefore far too cheap: 'There is no tax on aviation fuel. [...] Additionally, no VAT [Value Added Tax] is paid on aviation transactions (although the majority of EU states impose VAT on domestic air travel). All this means that each year the aviation industry in the European Union receives over 45 billion in tax concessions and other subsidies.' Of course, industry supporters dispute these claims. They point to recent increases in air passenger duties and tourism taxes which have, they conclude, resulted in air travel being highly taxed in relation to other forms of transport. The International Air Transport Association (IATA) portrays an industry facing 'thousands of taxes and fees on its operations and services, [... with] the revenue raised from such taxes [...] far outweighed by the economic benefits that are forgone as a result' (IATA, 2013b). But, nonetheless, 
Joaquín Almunia, Vice-President of the European Commission responsible for Competition Policy, announced in July 2013 a public consultation on state subsidies in aviation which would set out plans to reform operating costs at regional airports in an effort to avoid 'duplication of unprofitable airports' and the under-use of regional facilities (2013: 2). Indeed, the proliferation of regional point-to-point airports in Europe has resulted in a number of airports operating significantly below capacity or even being abandoned as in the case of Spain's $£ 1.1$ billion Ciudad Real Airport (which closed in 2012 three years after opening as an 'overspill' airport for Madrid Barajas) and Sheffield City and Plymouth airports in the UK. Such closures are not limited to Europe as the failure of Yangyang International Airport in South Korea aptly demonstrates (Sudworth, 2009).

Yet, campaigners against aviation do not simply argue that the environmental costs of expansion outweigh its economic benefits, but rather question the underlying benefits of increased connectivity for economic growth and wellbeing. In its assessment of aviation and connectivity, which was funded by World Wide Fund for Nature (WWF), Royal Society for the Protection of Birds (RSPB) and the local residents' association, HACAN ClearSkies (Heathrow Association for the Control of Aircraft Noise), the Dutch environmental consultants, CE Delft, throw doubt on the evidence-base supporting the privileged status of air travel as an 'economic catalyst', and criticise the capacity of traditional cost benefit analysis to take full account of social and environmental costs of flying. Indeed, the report argued that 'there is no proof that extra connectivity results in economic growth' and concluded that 'studies that claim a causal relationship between expansion and growth were found to have serious methodological shortcomings' (CE Delft, 2013: 2).

Equally, what we earlier posited as market transitions in the global aviation industry, particularly since the 2008 economic recession, are being understood alternatively as the first signs of a transport revolution in which commercial aviation is already suffering the effects of the economic downturn, the increasing substitution of highspeed rail for air routes and the rising price of fuel (Gilbert and Perl, 2010). The cost of aviation fuel, Gilbert and Perl estimate, increased threefold from 2002 to 2006, only to double in 2008 before falling back to 2006 prices by late 2008 . These rising fuel costs and an economic recession meant that the global aviation industry lost over $\$ 10$ billion in 2008 (2010: 95). Rising prices, Gilbert and Perl go on to claim, will threaten cheap flights, lower passenger demand and contract the market for US domestic air travel by 2025 and international air travel thereafter (2010: 96) as flying for leisure becomes so expensive that people 'take just once-in-a-lifetime holidays involving a grand tour of another continent' (2010: 258).

Overall, therefore, claims for connectivity and assessments of the future economic success of aviation demonstrate the difficulties of reaching agreement over a sustainable future for aviation. Is it an industry in terminal decline or is it in transition? Should governments treat it differently from other industries as air travel triggers other forms of economic development or not? These very questions themselves, let alone the responses to them, cannot be divorced from other judgments such as the likelihood of peak oil and the availability of substitute forms of transport or alternative fuels, all of which inform part of the assessment of aviation as an industry facing the threat of terminal decline. We will address these issues later, but first we examine the assessment of the social impacts of aviation that structure contemporary debates.

\section{Claims for Social Progress}

As we alluded to above, flying has become intrinsically tied to our everyday lives. Air travel facilitates what certain societies now see as needs and/or aspirational goods, 
be it foreign holidays, round-the-year availability of fresh foodstuffs, foreignproduced consumer goods, and opportunities for new encounters, employment, and education. Cheap air travel in such instances becomes a tool to advance social mobility and to spread social welfare. Yet, at the same time, we have noted how aviation creates negative impacts on social wellbeing, such as concerns over airport security, the global transmission of infectious disease, or the continuation of forms of social injustice and inequality.

Assessing such outcomes and assigning some form of value to them rests on particular visions of society, how one delimits 'social' outcomes, and the responsibility attached to aviation for the existence of such benefits or injustices. For example, within hours of aircraft being grounded in northern European airspace due to the volcanic ash cloud caused by the 2010 eruption of Eyjafjallajökull, news reports and social media sites carried stories of stranded passengers, fears of lost holidays and shortages of fresh green vegetables and cut flowers, all of which revealed our dependence on the availability of cheap air travel. Yet, these stories were quickly countered by those revelling in the delight of empty skies, the absence of aircraft noise and the return, albeit short-lived, to the social benefits of 'slow living' (see Budd, Griggs, Howarth and Ison, 2011). Indeed, in an earlier voicing of such criticisms, Mark Ellingham, founder of the Rough Guides travel books, commented on society's addiction to 'binge-flying', claiming that 'we now live in a society where, if people have nothing to do on a Saturday night, they go to Budapest for 48 hours. We fly anywhere at the slightest opportunity, 10 times and upwards a year' (Observer, 06 May 2007).

With these rival understandings of the social outcomes of air travel in mind, we focus our attention on three contentious elements of aviation's social footprint: fairness, cohesion and social justice. The low-cost revolution in aviation, as we have stated, has opened up international air travel and exchanges to lower income groups. As Shaw and Thomas (2006: 209) argue, this extended opportunity for 'holidays, short breaks, visiting relatives, educational, cultural and religious exchanges' has significant consequences for 'social and spatial equality.' More importantly, they argue that the 'democratisation' of air travel has transformed 'people's desire for air travel into a consumer expectation, a norm or even a right.' Yet, these social impacts of air travel are arguably still reserved to a minority of the world's population. Even within mature aviation markets such as the UK, flying remains dominated by an affluent elite. In a 2011 survey of passengers at London airports, managerial, administrative and professional workers accounted for over 80 per cent of leisure travellers at Heathrow and almost 75 per cent of passengers at Gatwick. Even at Luton and Stansted, airports that are predominately used by lowcost carriers, managerial, administrative and professional workers still dominated, although there was evidence of a shift towards more supervisory, clerical and junior managerial or administrative workers (who accounted for 45.6 per cent of passengers at Stansted as opposed to 27.5 per cent from higher or intermediate managerial or professional employment) (CAA, 2011: 76).

These imbalances in rates of flying raise critical issues for any assessment of aviation's social value. Like aviation's economic impacts, its social benefits are being increasingly challenged. HACAN ClearSkies, the local resident association opposing expansion at London Heathrow airport, has argued that flying actually reproduces or exacerbates social inequalities, claiming not least that second-home owners with properties abroad are the most frequent flyers (HACAN, 2003). More broadly, the negative impact of mass tourism on local cultures and environments, which has been fuelled by the availability of flight-based package holidays, has long been recognised (Whitelegg, 2000). 
Such broader impacts, well beyond the narrow confines of airports, question the claiming of air travel as a 'right'. In the first instance, the costs of aviation are disproportionately experienced by those living near airports or on flight paths through rising levels of noise pollution. Within this perspective, air travel is a practice undertaken by many at the expense of the few (although whether the 2 million people thought to be affected by aircraft noise from Heathrow airport counts as 'few' is an interesting point given that approximately 68 million passengers use the airport each year). While noise pollution may well figure as an environmental dimension of air travel, its impacts on education and community wellbeing are significant. According to a 2013 study around Heathrow, children living under flight paths take an additional two months to develop reading skills than other children (BBC, 2013). Annoyance from noise can also provoke tensions as it interrupts normal daily activities and communication (Hume and Watson, 2003: 57). More broadly, airport operations and expansion can threaten the destruction of village communities and impact adversely on perceptions of empowerment and social justice when local community campaigns are defeated and expansion goes ahead (see Griggs and Howarth, 2002). Of course, this latter impact may owe more to government and its consultation processes than to aviation itself.

Yet, with climate change and rising greenhouse gas emissions from aviation, the direct costs of flying are being felt by broader swathes of the globe and are impacting on other species. Campaigners have been quick to connect flying to such negative outcomes, with the local resident group, Stop Stansted Expansion, inviting the Inuit leader, Aqqaluk Lynge, to speak on its behalf in July 2007 against airport expansion and on the dangers of climate change to the Arctic ecosystem at a public inquiry into increasing capacity at the airport (Stop Stansted Expansion, press release, 21 July 2007). More recently, in a 2010 viral internet campaign, Plane Stupid, the direct action network against airport expansion, drew attention to the impact of flying on other species and their habitats. It released a short film of polar bears falling from the sky, crashing into buildings and parked cars against the background noise of planes passing overhead. The film ends with the message that 'an average European flight produces over $400 \mathrm{~kg}$ of greenhouse gas for every passenger...that's the weight of an adult polar bear. ${ }^{1}$ But, whatever the power of such visual rhetoric in its defence of the rights of other species, it also neatly leads us to consider the environmental impacts of flying, which is our third primary faultline within the politics of aviation futures.

\section{Claims for environmental protection}

As Budd and Budd in Chapter 4 of this volume show, aviation creates a range of negative environmental impacts including noise and local air pollution which can, over time, exacerbate existing health concerns and lead to a range of physical and mental health impairments (Hume and Watson, 2003). Airports also generate significant volumes of surface access traffic which contributes to local air pollution (Whitelegg, 2000: 8-11). They also promote development of surrounding (often rural) areas and their presence can disrupt habitats and/or alter natural water basins.

A October 2012 report on air quality and aviation expansion in the UK, undertaken by the Laboratory for Aviation and the Environment at the Massachusetts Institute of Technology and the Energy Efficient Cities initiative at Cambridge University, estimated that 110 people die early each year in Britain from airport emissions; a figure which was calculated to rise to 250 early deaths a year by 2030 . This rise in the number of early deaths was explained by the greater use of airports, growing

${ }^{1}$ See www.planestupid.com/polarbears, retrieved 22 July 2013. 
and ageing populations, and the increased impact of aviation emissions in what was determined to be a cleaner atmosphere in the future (Barrett, Yim, Stettler and Eastham, 2012: 5). To tackle rising air pollution, the report suggested nearmitigation measures such as removing sulphur from aviation, single engine taxiing, the electrification of ground support equipment and avoiding using aircraft auxiliary power units, as well as considering prevailing winds and population density in decisions to expand airports (2012: 4-5).

The extent of these localised impacts, their relative weighting in decision-making, and the effectiveness of measures to offset them is one of the fault-lines structuring the policy arena of commercial aviation. As Bröer discusses in Chapter 11, reducing noise pollution has been a constant demand of local residents and those living under flight paths since the introduction of jet aircraft in the 1960s. Indeed, extensive consultative machinery has been put in place to manage noise impacts on local communities. Yet, these interventions and the introduction of quieter aircraft have done little to reduce demands to lower noise pollution, which remains one of the primary causes of local resident mobilisation against airports. Direct auditory damage from aircraft is said to be rare, but with no agreed standard or decibel level at which noise impacts are deemed to become significant, it is difficult to assess noise and its impacts on levels or perceived levels of annoyance, sleep disturbance and stress (Hume and Watson, 2003). If anything, the contradictions of noise pollution have increased as scientific evidence has come to question the accepted decibel levels at which noise becomes irritating to those subjected to it.

Turning to the global environmental impacts of air travel, all stakeholders engaged in the debates surrounding the future of aviation broadly accept that aviation contributes to rising levels of carbon emissions. Fault-lines exist however over the extent of its contribution; the relative importance of such emissions compared with those of other industries; the rate of aviation emissions growth in the short and medium-term; and whether or not technological developments or trading schemes can effectively reduce or offset aviation's contribution to rising carbon emissions (Bows, Anderson and Upham, 2009; Gössling and Upham, 2009). Indeed, as we suggested above, although commercial aviation currently accounts for around $3 \%$ of all carbon dioxide $\left(\mathrm{CO}_{2}\right)$ emissions that result from human activities, if current growth forecasts prove accurate, the number of annual aircraft departures could increase from 31 million in 2012 to 59 million worldwide by 2030 (ICAO, 2013) with potentially serious global implications for the global climate.

In the United Kingdom, reducing carbon emissions from commercial aviation has been identified as one of the primary challenges facing the British government if it is to meet its commitment to reduce carbon emissions by 80 per cent by 2050 (Anderson et al., 2005; Cairns and Newson, 2006). The UK Committee on Climate Change (2009) predicted that aviation's contribution to UK greenhouses gas emissions will increase to 25 per cent by 2050 if aviation capacity continues to expand, thereby requiring other sectors to reduce their emissions disproportionately if the UK is to meet its reduction targets. Yet, two significant uncertainties hang over this estimate. First, as the Coalition government acknowledged in its 2011 scoping document, predictions of continued air travel expansion may well fail to incorporate adequately into their calculations the impacts of peak oil and rising oil costs on passenger demand given the uncertain development of alternative fuel sources.

Secondly, the radiative forcing or warming effects of aviation emissions are still not fully understood because they occur at high-altitude and go beyond the impact of carbon dioxide (Lee et al., 2009). Contrails are believed to trap long-wave radiation from the ground adding to global warming, while soot and sulphate emissions are implicated in the formation of anthropogenic cirrus clouds. Yet, their impact on 
global warming and cooling are far from straightforward and thought to vary by latitude, altitude and season (over the Arctic, for example, their impact may be more significant) (Whitelegg and Williams, 2000: 19; Schumann et al., 2012; Jacobson et al., 2012). It is misguided therefore to delimit aviation's impact on global warming to its level of carbon emissions, although much uncertainty remains as to the impact of aircraft emissions at high-altitude (Whitelegg and Williams, 2000: 19-20; Lee et al., 2009). Indeed, updating IPCC estimates with 2005 data, as well as including aviation's impacts on cirrus cloud formation, Lee et al. (2009) concluded that aviation contributed 4.9 per cent of radiative forcing, higher than its $\mathrm{CO}_{2}$ impacts alone.

Worldwide, growing awareness of air travel's deleterious social and environmental impacts has prompted aircraft manufacturers, airlines, and airport operators to invest in new, less carbon intensive, aeronautical technologies and adopt new operating procedures to lower aviation's carbon footprint. These include the introduction of more fuel efficient aircraft such as Airbus' A320neo (new engine option) and Boeing's 737MAX, research and development into alternative fuels, and enhanced air traffic management techniques such as continuous climb departures and precision area navigation. In Europe, the SESAR programme aims to confer significant environmental benefits through air traffic management efficiencies associated with a single European sky.

Yet, as Chapter 4 in this volume details, the effectiveness of these technologies is highly contested. While industry representatives point to a record of technological advances in producing quieter and more fuel-efficient aircraft and engines as evidence of its capacity for technological change, its detractors raise the complexities of the technological advances required to wean aviation off kerosene and the broader negative impacts that such a transformation may engender. Take for example using aviation biofuels as a substitute for conventional Jet A/A1 fuel. The European Biofuels Flightpath programme, which involves the European Commission, carriers including Lufthansa, Air France/KLM and British Airways, and biofuel producers, aims to develop a supply chain capable of producing 2 million tonnes of sustainably-produced paraffinic biofuels by $2020 .^{2}$ In its 2012 report on biofuels and aviation, IATA (2012b: 9) speaks of a 'seamless transition to lowcarbon air travel.' However, AirportWatch, a UK umbrella organisation of environmental groups and local resident groups opposed to expansion, dismisses biofuels as a 'dangerous diversion' (2011: 2). They question the sustainability of biofuels and draw attention to the fact biofuel production is not carbon neutral, and the need to grow sufficient quantities of suitable feedstocks may induce land grabs by speculators, lead to the destruction of forests, and may compete for land against food crops. Indeed, it concludes that 'the misguided rush into biofuels will encourage us in the rich world to believe we can continue to fly - and drive - even more than we now do' (2011: 2).

In response to the growing environmental and public relations challenge it faces, the aviation industry has set itself a number of legally-binding and voluntary targets to reduce levels of aircraft noise and greenhouse gas emissions in an attempt to improve its environmental credentials and facilitate future expansion. In 2005, a group of UK airlines, airport operators and aerospace manufacturers founded Sustainable Aviation to detail 'the collective approach of UK aviation to tackling the challenge of ensuring a sustainable future for our industry' (Sustainable Aviation, 2013). In 2009, the not-for-profit aviation association the Air Transport Action Group (ATAG), an international consortium of over 50 major aerospace companies,

\footnotetext{
${ }^{2}$ See http://ec.europa.eu/energy/renewables/biofuels/flight_path_en.htm retrieved 28 July 2013.
} 
established a number of new aviation sustainability targets. These included a commitment to increase fuel efficiency by an average of 1.5 per cent per year between 2009 and 2020, to stabilise emissions from 2020 through carbon neutral growth and a (aspirational) target of reducing aviation emissions by 50 per cent by 2050 compared to 2005 levels (ATAG, 2013).

More recently, in June 2013, IATA agreed to the development of a global emissions trading system to cap aviation emissions from 2020. This followed the suspension of intercontinental flights from the European Union's emissions trading scheme (ETS) to allow ICAO, the United Nations regulatory body overseeing aviation, to negotiate a global agreement, given the opposition and challenges by China and the United States to the scheme. Time will tell whether this represents a significant shift in the thinking of the aviation industry or another attempt to defend air travel from, or delay the implementation of, top-down regulation by governments and international bodies. However, if reactions to the implementation of the EU ETS are anything to go by, the determination of any global market will no doubt be highly fraught with political standoffs over the calculation of emissions across the industry, the weighting of reductions between mature and immature markets, and the lobbying of governments by powerful aerospace companies. As it stands, the EU has sought to exercise its political muscle, warning that for it to extend its exemption of intercontinental flights, ICAO must make 'adequate' progress on a global emissions deal by autumn 2013.

But, the EU ETS, and emissions trading in general, has itself been brought under scrutiny (see Chapter 3 and Chapter 5 in this volume). Critics of the scheme have warned that it is not a 'complete policy solution' and have drawn attention to its failure to take account of radiative forcing impacts and of the potential to expand absolute aviation emissions through offsetting while calling for tougher caps on aviation and rises in the percentage of permits that are auctioned rather than freely distributed to carriers (Lockley, 2011: 31-32). Amidst these considerations, the price of carbon, and how far it will need to rise to bring about reductions in flying, becomes another fault-line dividing the competing stakeholders in the aviation policy arena.

This fault-line over the efficacy of emissions trading exposes divisions over the limits of voluntary or self-regulation and the necessity for external or government regulation of air travel's environmental impacts (Daley and Preston, 2009). The limits of emissions trading, as well as technological change, require, it is argued, government action to lower demand for air travel, including cancelling plans for expansion, ending short-haul flights and raising taxation on airline tickets and aviation fuels (see Lockley, 2011). These measures are to go hand in hand with the broader substitution of rail for short-haul flights, greater encouragement of behavioural change and the use of technology such as video-conferencing for business meetings. Indeed, high-speed rail has been offered up to government as a ready-made 'policy solution' to the dependency on aviation, although it too has attracted criticism over its environmental credentials, as Dobruszkes and Givoni in Chapter 8 explain.

In short, this assessment of the environmental, and social and economic, impacts of aviation demonstrates the number of uncertainties, ambiguities and fault-lines dividing protagonists in the aviation policy arena. At the same time, it illustrates how any assessment of sustainable futures for air travel cannot be divorced from the policy instruments at the disposal of decision-makers, different worldviews or frames, and the priorities given to different outcomes. On the one hand, any critical evaluation of the environmental impacts of air travel rests in part on the additional assessment of how far alternative measures can be made to lessen or regulate 
such impacts. On the other hand, these considerations cannot be made in isolation from one another for as the ethos of sustainable development dictates, no single priority should be privileged in any consideration of aviation's future. With this in mind, we offer a few concluding words about how these different dimensions of aviation and policy instruments are being brought together in different scenarios or aviation futures.

\section{Aviation Futures}

Drawing on the work of Griggs and Howarth (2013), we analyse four different viewpoints or scenarios for the future of aviation: post-carbon, high-modernism, market regulation, and demand management. Post-carbon scenarios predict the inevitable collapse of aviation in the near future. Echoing the 'presaging apocalypse' myth that frames may debates surrounding climate change (Hulme, 2009), continued aviation expansion is problematized as an unsustainable and ultimately detrimental practice of modern capitalism. Here peak oil, rising carbon emissions, and the social stigma of flying have together allegedly triggered the first transformations in the managed decline of air transport. Typically, in an article in The New Republic entitled 'the future of aviation, the end is nigh' (26 April 2010), Bradford Plumer speculates on the end of mass aviation, suggesting that 'early signs of an aviation apocalypse are already upon us.' Pointing to the increasing articulation of flying as a 'social stigma', peak oil, emissions trading and increasing costs of flying, he suggests the end of cheap flights and the return to the elite jet-set flying practices of the 1930s. But, in its more radical variants, advocates of postcarbon futures even portray aviation as the 'new' tobacco industry in its irresponsible corporate profit-seeking, its 'capture' of government departments (as evidenced by the absence of tax on aviation fuel) and its harmful impact on individuals, particularly on those who do not fly but will suffer from the severe impacts of climate change on their local environments, and finally its ultimate inability to maintain its corporate reputation within public opinion as scientific evidence mounts against it. Interestingly, in response to British Airways' launch of a new domestic flight between London Gatwick and Newquay airport in Cornwall, which coincided with the ban on smoking in public places in England in June 2007, Greenpeace placed full-page advertisements in UK broadsheet newspapers that mocked BA's '120-a-day habit' to domestic flying and suggested it was time for the airline to 'quit its dirty habit'. A large image of an aircraft trailing cigarette smoke as opposed to contrails across an otherwise clear blue sky accompanied text that stated 'only tobacco companies are as cynical, and they took decades to publicly accept the damage their products cause. With climate change we simply don't have that long'.

In contrast to this approach, high-modernist or techno-managerialist scenarios foresee continued expansion in aviation and place their faith in continual human and scientific progress (Hulme 2009: 351). Proponents of high-modernism thus reject scare-mongering stories of the impending demise of aviation. On the contrary, they stress aviation's crucial role in the workings of the modern economy, presaging the dependence of advanced capitalism on the 'connectivity' offered by air transport. The challenges of aviation's impact on climate change are thus conceptualized as a set of manageable risks which given the right financial incentives can be mitigated through technical innovation and human ingenuity. Significantly, high-modernist scenarios thus marry in part with the discourse of ecological modernisation in which the promises of green technology are said to be able to ensure a 'positive sum game' in which both aviation growth and environmental protection are possible (see Hajer, 1995; Mol, 2000). In other words, aviation can continue to expand as a 'clean' or sustainable industry. 
Market-regulation scenarios view air travel as central to the workings of the modern economy, but recognise that in the future flying will be subject to market-style handsoff restrictions or forms of regulation, which may see the number of flights capped or go into decline. These scenarios tend to put their faith in 'soft' regulatory mechanisms, economic instruments such as cap and trade schemes and carbon offsetting for tackling aviation's impact on climate change. Such mechanisms induce, it is claimed, forms of 'responsible agency' or indeed responsible corporate agency (Paterson and Stripple, 2010), which limit the role of government to setting overall limits to emissions and managing incentives. In fact, cap and trade models even allows for the continued expansion of aviation as the industry can continue to buy allowances from other industries or credits from 'clean energy' projects. In other words, expansion is possible if the aviation industry demonstrates its capacity to expand whilst reducing or allowing for its environmental impact. Put alternatively, it is an approach that ultimately takes account of the economic importance of aviation, enabling it to continue as a 'necessary evil', albeit as one which expands either through its internal efficiencies or less charitable at the expense of other industries.

Finally, demand management scenarios conceptualise the future of aviation as an industry under managed decline in which government takes the lead in lowering demand for air travel, encouraging new forms of sustainable transport, raising taxation on flying and imposing strict emissions criteria. Flying persists, but only as 'an option for truly urgent travel', replaced by rail and even wind-powered hybridised ships (Gilbert and Perl, 2010: 257). Examining measures to facilitate such transitions in the United States, Gilbert and Perl thus make much of the demand for strategic leadership by government (2010: 238). They point to three primary developments to launch the required transport revolution: first, the creation of a new public Transport Development Agency to 'plan, facilitate and monitor transport redesign' (2010: 239); secondly, the end to all existing plans and programmes for airport expansion (and road-building); and thirdly, the taxation or increased taxation of oil-based transport fuels, including aviation fuel (2010: 239-247). Importantly, proponents of demand management eschew the limits of self-regulation in favour of government intervention and regulation to reduce global social and economic dependence on flying.

Of course, the boundaries between these aviation futures are porous. It would be misguided to draw too clearly defined lines or oppositions between them. But, within each scenario or viewpoint, policy instruments or social, economic and environmental impacts of aviation are given distinct meanings and attributed specific consequences. Which scenario or aviation future wins out in the end rests to a large degree on political negotiation and persuasion, and how rival coalitions are able to structure the terrain of argumentation over air travel. Interestingly, in its determination of future scenarios for European aviation in 2035, Eurocontrol (2013: 10-11) determines the 'most likely' scenario to be that of 'regulated growth' of aviation, arguably more in line with our conceptions of market-regulation than those scenarios of demand management, high-modernism or post-carbon worlds. These latter scenarios align respectively more with Eurocontrol's visions of a 'happy localism' with less globalisation and more trade and travel within Europe, 'global growth' through technological advance, or a 'fragmenting world' of higher fuel prices and reduced trade and transport integration. Yet, as this analysis of competing scenarios underlines, how we interpret the future of aviation rests on our broader values and beliefs concerning the challenges facing society and how governments and other stakeholders put in place and coordinate the multiple arenas in which a dialogue over the future of our society can be held. In other words, aviation futures cannot be reduced to the narrow confines of the technical effectiveness or feasibility of policy instruments; they merit a much wider dialogue, which explores how we imagine the futures of our societies and practices of government. 


\section{Aims of the volume}

This volume seeks to foster such a dialogue and contribute to the difficult and challenging processes of generating a new policy settlement in aviation. More specifically, it begins to unpick and critically evaluate the maze of rival demands, policy positions and institutional biases that currently structure the politics of aviation. Much has been written on the future of aviation since the foundations for the debate that were laid down 10 years ago in Paul Upham et al's (2003) seminal work Towards Sustainable Aviation. Yet, it is quite clear from the contributions to this volume that while progress has been made in the intervening decade, we are far from resolving the tensions that exist between economic and commercial imperatives for air transport growth on the one hand and environmental responsibilities on the other. Indeed, in the shifting global context of economic transformation, new and challenging evidence of climate change impacts, and emergent international regulatory regimes, it is timely to critically evaluate the current status and future prospects for sustainable aviation, and other aviation futures.

With these aims in mind, the volume goes on to examine the multiple fault-lines of aviation politics, which have been established, albeit in a cursory manner, in this opening chapter. It asks leading names in global air transport and aviation policy research to offer their own innovative assessments of the future of commercial air travel in their particular fields. Each individual contribution thus engages with important issues of contemporary debates within aviation policy arenas. Collectively, however, they come together to refine understandings of contemporary debates across aviation policy arenas and offer a broad assessment of the prospects for change in how we reframe our understandings and practices of flight.

The volume is unashamedly multidisciplinary in its ambitions. It brings together the work of geographers, political theorists, climate scientists, economists, planning experts, sociologists and transport specialists. At the same time, it draws upon a range of comparative cases, seeking to investigate the interplay between the specific dynamics of local institutions and practices and more global or universal economic and political drivers. Importantly, many of the chapters presented here were delivered as part of a British Economic and Social Research Council Seminar Series into the politics and policies of sustainable aviation that ran from January 2011 to September 2012. This series brought together multiple policymakers, practitioners and campaigners from across the aviation policy arena. This valuable interaction with these multiple stakeholders helped polish the contributions to this volume and shape its focus - and we would like to thank all participants in this series for their valuable insights, which are too numerous to mention.

\section{The Contributions}

The book is divided into three principal sections. The first examines the scale and the scope of the contemporary sustainable aviation challenge. In Chapter 2, John Bowen examines the changing spatiality of global air service provision as the balance of aviation power shifts inexorably away from North America and Europe towards countries in the Middle East, Latin America and China. He suggests that the $21^{\text {st }}$ century aeromobile world will look very different from that of the $20^{\text {th }}$ century, but concludes that the long-term growth of the industry in unlikely to be reversed. Critically assessing the impact of growing emissions from aviation given the predictions for growth in emerging markets, Alice Bows-Larkin and Kevin Anderson quantify in Chapter 3 the climate challenge facing air travel. They offer a detailed analysis of a range of different emissions and future climate scenarios, which evaluates the extent to which carbon reduction must be achieved in other industrial 
sectors if aviation is to be allowed to continue to expand at its present rate while avoiding catastrophic climate change and significant rises in average global temperatures. They conclude that governments and societies should ultimately question whether aviation expansion should continue, given the limited technological options for decarbonisation.

The second section of the volume, which examines different challenges or fault-lines in addressing issues of sustainability in air travel, opens with further discussion of the technological options available to aviation. Chapter 4, by Lucy and Thomas Budd, documents the role of aeronautical technology in improving the environmental performance of commercial aviation. By focusing on the environmental impacts of all the stages of the air service delivery chain, from aircraft construction through routine flight operations and maintenance to eventual airframe decommissioning, they examine the potential environmental improvements and efficiency gains that may be afforded by the introduction of new technologies such as biofuels, new airframe configurations, open rotor engines and more sophisticated air navigation and flight planning procedures.

This assessment of the technological options open to aviation is followed by an examination of the mechanics of emissions trading ands its applicability to aviation, the effectiveness of which is increasingly contested within aviation policy arenas. In Chapter 5, Annela Anger-Kraavi and Jonathan Köhler analyse aviation's inclusion in the European Union's Emissions Trading Scheme (ETS). By performing a detailed economic assessment of the potential impacts of ETS on the aviation sector, they conclude that contrary to many concerns, there is likely to be very little adverse economic impact on the air transport sector and suggest that, if a stable and sufficiently high carbon price can be maintained, the ETS may well provide a strong incentive for airlines to re-equip their fleets with more modern and less polluting aircraft.

In Chapter Six, Charlotte Halpern examines an area of aviation policy that is often underreported in the literatures on sustainable aviation - namely the complex interplay that exists between airport actors. Drawing on her extensive research in Europe, she shows how privatisation and the complex interplay between public and private ownership has rescaled in part the territorial dimension of airport activities which have become full-blown economic actors with high-levels of autonomy. Indeed, she posits that these transformations can be tied to the limited impact of anti-airport campaigns over the long-term development of major European hubs.

One of the long-term annoyances of airport operation has been noise pollution, which has mobilised local campaigns against aviation expansion for the last fifty years or more. In Chapter 7, Christian Bröer addresses this salient issue of noise pollution, analysing the political history of aircraft noise annoyance and its relationship to sustainability. Analysing community sensitivity to aircraft noise and noise management and mitigation measures at Amsterdam Schiphol and Zurich Kloten airports, he suggests that citizens' perceptions of aircraft noise are shaped by policies to tackle noise, leading paradoxically to an intensification of the annoyance associated with aircraft noise.

However, more recently, alongside demands to lower noise and air pollution from aviation, transport lobbyists and aviation campaigners have argued that high-speed rail as a substitute for short-hauls flights offers an effective means of lowering the impact of rising aviation emissions on climate change. Frederic Dobruszkes and Moshe Givoni in Chapter 8 examine the potential of high speed rail in Europe and the extent to which it might confer environmental benefits over flying. They demonstrate how judgements rest for example on comparative load factors and the 
use made (or not) of runway capacity released by the switch to rail, concluding that there are multiple challenges to overcome if rail integration with airports is to be more than a business opportunity for airlines, airports and train companies.

We close this second part of the volume with an analysis on the challenges posed by the congestion within our skies and the management of the risks it poses, and are posed to it by natural events. Peter Adey, in Chapter Nine, discusses the future sustainability of the socio-technical regime of aviation. Drawing on his research on preparedness and crisis management of European airspace that was triggered by the disruption caused by the ash cloud from the eruption of Iceland's Eyjafallajökull volcano, Adey alerts us to the inherent vulnerabilities of the air transport system to natural events. He suggests that arrangements put in place to respond to moments of crisis are not unproblematic, raising questions over state sovereignty and the airlines' suspicion of regulation or lack thereof.

The final section of the volume considers the prospects for change in the aviation policy arena and the difficulties governments face in addressing the 'wicked issue' posed by aviation. In Chapter 10, James Connelly investigates the brakes placed on policy change in aviation by the continuation of 'politics as usual' or what he terms to be the continued adherence to underlying presuppositions, which guide the political and economic action of ministers and policy-makers. He concludes that these unacknowledged presuppositions constrain advances to integrate environmental concerns in aviation. Indeed, the prospects for change in aviation policies, Connolly suggests, rest on the political questioning and recognition of this set of default positions favouring aviation expansion.

The difficulties and opportunities of contesting and overcoming such 'default positions' are subsequently explored in the contributions of Ute Knippenberger and Steven Griggs and David Howarth. In Chapter 11, Ute Knippenberger analyses the conflicts that have accompanied the development of Germany's largest airport at Frankfurt/Main. She demonstrates how these conflicts are structured by tactical descriptions of space and conceptions of airports as elements of large technological systems. In so doing, Knippenberger reveals the necessity of situating airports and their local governance within different scales, from neighbouring cities to the large labour market stretching up to $100 \mathrm{~km}$ from the airport.

In Chapter 12, Steven Griggs and David Howarth analyse the difficulties facing governments in forging new policy settlements in aviation, as well as those facing anti-aviation expansion campaigners in holding governments to their commitments to manage demand for air travel. They evaluate the apparent policy reversal in British aviation policy in May 2010 when the incoming Coalition government ended plans to build a third runway at London Heathrow airport. Heathrow expansion and the politics of the Coalition government present a critical case study for how we conceptualise opportunities for alternative aviation futures, as James Connolly suggests in his contribution to this volume. In this concluding chapter, Griggs and Howarth thus advance the assessment of the political backlash to the 2010 policy reversal. They suggest that the challenges facing campaigners and government, while emanating in part from the shifting political context, cannot be divorced from the continued resonance of the logic of aviation expansion embedded in British institutions at the end of the Second World War.

Before turning to the individual contributions that make up this volume, we want to make one final clarification. This volume does not endorse any specific future vision or policy scenario for air travel. Its ambitions are more humble, for we hope that in some small way it will inform continued debates about the extent to which we can generate a new policy settlement in aviation. While we recognise that the benefits of 
aviation must not be decoupled from the negative impacts they create, each contributor offers his or her own critical assessment of the policy implications or prospects for change in their specific field or dimension of aviation futures. Ultimately it is incumbent on researchers to work with politicians and industry to help inform future decision making that promotes more sustainable aviation for the collective good of individuals, companies, nations and planet Earth alike. We hope that this volume takes a step in that direction.

\section{References}

Adey, P. (2010) Aerial life. Spaces, Mobiliites, Affects Chichester, Wiley-Blackwell.

Air Transport Action Group [ATAG] (2012) Aviation. Benefits beyond borders. Retrieved from www.benefitsbeyondborders.com

Air Transport Action Group [ATAG] (2013) Facts and Figures, retrieved from www.atag.org/facts-and-figures.html on 22/07/2013.

Airlines for America. (2013). Annual Results World Airlines, retrieved from http://www.airlines.org/Pages/Annual-Results-World-Airlines.aspx on 28/06/2013.

AirportWatch (2011) Beware Aviation Biofuels, London, AirportWatch.

Almunia, J. (2013) Introductory remarks on new state aid rules for airports and airlines, press conference, Brussels, 03 July, Speech/13/606.

Anderson, K., Shackley, S., Mander, S. and Bows, A. (2005) Decarbonising the UK: Energy for a Climate Conscious Future, Manchester: Tyndall Centre.

Apter, D.E. and Sawa, N. (1984) Against the State. Politics and Social Protest in Japan, Cambridge, Mass.: Harvard University Press.

Barrett, S., Yim, S., Stettler, M. and Eastham, S. (2012) Air Quality Impacts of UK Airport Capacity, Cambridge, Mass.: Laboratory for Aviation and the Environment, MIT.

Boeing. (2012). Current Market Outlook, 2012-2031 Seattle, WA, Boeing Commercial Airplanes.

Bows, A. with Anderson, K. and Upham, P. (2009) Aviation and Climate Change: Lessons for European Policy, London, Routledge.

British Broadcasting Corporation [BBC] (2013) Pupils Learning Affected by Heathrow Noise, BBC News 29 March 2013. Retrieved from http://www.bbc.co.uk/news/uk-england-london-21975462 on 27/07/2013.

Budd, L., Griggs, S., Howarth, D. and Ison, S. (2011) A Fiasco of Volcanic Proportions? Eyjafjallajökull and the Closure of European Airspace, Mobilities 6(1), 31-40.

Cairns, S. and Newson, C. (2006) Predict and Decide. Aviation, Climate Change and UK Policy, Oxford: Environmental Change Institute. 
CE Delft (2013) The Economics of Airport Expansion. Consulting on the Limits of Economic Appraisal; Illustrating the Diminishing Returns to Connectivity. Summary. London, WWF, RSPB and HACAN ClearSkies.

Civil Aviation Authority (2011) CAA Passenger Survey Report 2011. A survey of passengers at Birmingham, East Midlands, Gatwick, Heathrow, Luton, Manchester and Stansted, London, CAA.

Committee on Climate Change (2009) Meeting the UK Aviation Target - Options for Reducing Emissions to 2050, London, Committee on Climate Change.

Daley, B. and Preston, H. (2009) 'Aviation and Climate Change: Assessment of Policy Options', in S. Gössling and P. Upham (eds.) Climate Change and Aviation. Issues, Challenges and Solutions, London: Earthscan, pp. 347-372.

Eurocontrol (2013) Challenges of Growth 2013, Brussels: Eurocontrol.

Gilbert, R. and Perl, A. (2010) Transport Revolutions. Moving People and Freight Without Oil, revised edition, London, Earthscan.

Gössling, S. and P. Upham (eds) (2009) Climate Change and Aviation. Issues, Challenges and Solutions, London, Earthscan.

Graham, A. (2008) Managing Airports. An International Perspective, $3^{\text {rd }}$ edition, Oxford, Butterworth Heinemann.

GreenSkies (2005) Rail Transport. The Sustainable Alternative For Air Travel in Europe, London, GreenSkies.

Griggs, S. and Howarth, D. (2002) An Alliance of Interest and Identity? Explaining the Campaign against Manchester Airport's Second Runway, Mobilization, 7(1), 4358.

Griggs, S. and Howarth, D. (2004) 'A Transformative Political Campaign? The New Rhetoric of Protest against Airport Expansion in the UK', Journal of Political Ideologies, Vol. 9, No. 2, pp. 167-87.

Griggs, S. and Howarth, D. (2013) The Politics of Airport Expansion in the United Kingdom. Hegemony, policy and the rhetoric of 'sustainable aviation', Manchester: Manchester University Press.

HACAN ClearSkies [Heathrow Association for the Control of Aircraft Noise] (2003) A Poor Deal, London, HACAN.

Hulme, M. (2009) Why We Disagree About Climate Change: Understanding Controversy, Inaction and Opportunity, Cambridge, Cambridge University Press.

Hume, K. and Watson, A. (2003) Human Health Impacts of Aviation in Upham, P., Maughan, J., Raper, D., and Thomas, C. (Eds.) (2003)Towards Sustainable Aviation, London, Earthscan, pp.48-76.

IATA [International Air Transport Association] (2007) Aviation Economic Benefits. Economics Briefing. Retrieved from www.iata.org/SiteCollectionDocuments/890700_Aviation_Economic_Benefits_Sum mary_Report.pdf on 17/07/2013. 
IATA [International Air Transport Association] (2012a) IATA Industry Forecast 20122016 Geneva, IATA.

IATA [International Air Transport Association] (2012b) IATA 2012 Report on Alternative Fuels, $7^{\text {th }}$ edition, Geneva, IATA.

IATA [International Air Transport Association] (2013a) Homepage, retrieved from www.iata.org/Pages/default.aspx on 07/07/2013.

IATA [International Air Transport Association] (2013b) Taxation, retrieved from www.iata.org/policy/Pages/taxation.aspx on 17/07/2013.

ICAO [International Civil Aviation Organisation] (2013). Key Facts Retrieved from http://www.icao.int/sustainability on 28/06/2013.

Jacobson, M.Z., Wilkerson, J.T., Babsubramanian, S., Cooper Jr., W.W. and Mohleji, N. (2012) 'The Effects of Rerouting Aircraft Around the Arctic Circle on Arctic and Global Climate', Climate Change 115: 709-724.

Kasarda, J.D. and Lindsay, G. (2012) Aerotropolis: The Way We'll Live Next, London: Penguin Group.

Lee, D.S., Forster, D.M., Newton, P.J., Wit, R.C.N., Lin, L.L., Owen, B. and Sausen, R. (2009) 'Aviation and Global Climate Change in the $21^{\text {st }}$ Century', Atmospheric Environment 43: 3520-3537.

Lockley, P. (2011) Aviation and Climate Change Policy in the United Kingdom. A Report for AirportWatch, London: AirportWatch, available at www.airportwatch.org.uk, accessed 04 August 2011.

Mol, A.P.J. (2000) ‘Ecological Modernization: Industrial Transformations and Environmental Reforms' in M. Redclift and G. Woodgate (eds) The International Handbook of Environmental Sociology, Cheltenham: Edward Elgar, pp. 138-149.

Paterson, M. and Stripple, J. (2010) My Space: Governing Individuals' Carbon Emissions, Environment and Planning D: Society and Space, 28(2), 341-362.

Randles, S. and Mander, S. (2009) 'Practice(s) and Rachett(s): A Sociological Examination of Frequent Flying' in S. Gössling and P. Upham (eds.) Climate Change and Aviation. Issues, Challenges and Solutions, London: Earthscan, pp. 245-272.

Rittel, H.W.J. and Webber, M.M. (1973) 'Dilemmas in a General Theory of Planning', Policy Sciences 4: 155-169.

Shaw, S. and Thomas, C. (2006) Social and cultural dimensions of air travel demand: hyper- mobility in the UK? Journal of Sustainable Tourism 14 (2): 209215.

Schön, D.A. and Rein, M. (1995) Frame Reflection: Toward the Resolution of Intractable Policy Controversies, New York: Basic Books.

Schumann, U., Graf, K., Mannstein, H. and Mayer, B. (2012) 'Contrails: Visible Aviation Induced Climate Impact', Atmospheric Physics. Research Topics in Aeropsace, pp. 239-57. 
Sudworth J (2009) South Korea's abandoned airports, BBC news online 18 May retrieved from http://news.bbc.co.uk/1/hi/world/asia-pacific/8055857.stm on 20/4/2013.

Sustainable Aviation (2013) Sustainable Aviation homepage, retrieved from http://www.sustainableaviation.co.uk on 29/07/2013.

Upham, P., Maughan, J., Raper, D., and Thomas, C. (Eds.) (2003)Towards Sustainable Aviation, London, Earthscan.

Urry, J. (2009) 'Aeromobilities and the Global' in S. Cwerner, S. Kesselring and J. Urry (eds) Aeromobilities, London: Routledge, pp. 25-38.

Walker, S. and Cook, M. (2009) The Contested Concept of Sustainable Aviation, Sustainable Development, 17(6), 378-390.

Whitelegg, J. (2000) Aviation: the Social, Economic and Environmental Impact of Flying, London: Ashden Trust, available at http://waag.co.nz/pdf/res0006.pdf retreived 15 July 2013.

Whitelegg. J. and Williams, N. (2000) The Plane Truth. Aviation and the Environment, London, Ashden Trust and Transport 2000.

World Commission on Environment and Development (1987) Our Common Future. From One Earth to One World. New York, United Nations. Retrieved from http://www.un-documents.net/wced-ocf.htm on 30/07/2013. 